\title{
Digenic inheritance of severe insulin resistance in a human pedigree
}

D B Savage, M Agostini, I Barroso, M Gurnell, J Luan, A Meirhaeghe, A-H Harding, G Ihrke, O Rajanayagam, M A Soos, S George, D Berger, E L Thomas, J D Bell, K Meeran, R J Ross, A Vidal-Puig, N J Wareham, S O'Rahilly, V K K Chatterjee \& A J Schafer

Nature Genet. 31, 379-384 (2002).

doi:10.1038/ng926

Owing to an copy-editing error that was implemented after the authors returned corrected proofs, the term 'doubly heterozygous' was substituted with the term 'compound heterozygous' throughout the text and in Table 1. Similarly, 'double heterozygotes' was erroneously substituted with 'compound heterozygotes'. Nature Genetics sincerely regrets these errors. 